UDC 57.017.23+112.7:352.465:151.643

\title{
QUALITATIVE ANALYSIS OF CELLULAR PRION IN THE CEREBELLUM OF THE WISTAR LINE RATS OF DIFFERENT AGE GROUPS
}

\author{
M. V. Kushkevych, V. V. Vlizlo \\ inenbiol@mail.lviv.ua
}

Institute of Animal Biology of NAAS, Vasyl Stus St., 38, Lviv, 79034, Ukraine

Prion infections (transmissible sponhioform encephalopathies (TSEs)) cause brain damage of humans and animals with lethal outcome. These diseases can be hereditary and sporadic. Neuronal degenerative changes, vacuolization of neurons, proliferation of astrocytes in the brain cortex, stem and cerebellum of the brain after death of TSE patients have been shown by histological research study. Cellular prion $\left(\operatorname{Pr} P^{C}\right)$ is needed for replication of pathological $\operatorname{Pr} P^{S c}$ which can cause infection development depending on the level of $\operatorname{Pr} P^{C}$ production in the different tissues. $\operatorname{Pr} P^{C}$ is membrane surface glicoprotein, that has important function including antioxidant, antiapoptotic protection, transport of certain ions and others. $\operatorname{Pr} P^{C}$ conversion into the pathological form leads to changes of the molecule conformation, consequently, to loss its physiological functions with a violation of metabolism in general.

The localization of $\operatorname{Pr} P^{C}$ in the cerebellum of rats of different ages has been demonstrated. The cellular prion was found in the cerebellar cortex, particularly in neurons of the molecular and granular layers, as well as in Purkinje cells. The localization of $\operatorname{Pr}^{C}$ was unchanged under age-related changes of the cerebellum. The amount of cellular prion was determined by the immunohistochemical and dot blot analysis methods. In particular, the $\operatorname{Pr} P^{C}$ level was the highest in cerebellum of six months rats and the lowest in cerebellum of thirty months animals.

\section{Keywords: RATS, CEREBELLUM, AGE CHANGES, CELLULAR PRION, IMMUNOHISTOCHEMISTRY, DOT BLOT}

\section{ЯКІСНИЙ АНАЛІЗ КЛІТИННОГО ПРІОНА В МОЗОЧКУ ЩУРІВ ЛІНІї WISTAR РІЗНИХ ВІКОВИХ ГРУП}

\author{
М. В. Кушкевич, В. В. Влізло \\ inenbiol@mail.lviv.ua
}

\author{
Інститут біології тварин НААН, вул. В. Стуса, 38, Львів, 79034, Україна
}

Пріонні інфекиії (трансмісивні спонгіоформні енцефалопатії, ТСЕ) спричиняють ураження мозку людини і тварин з летальним наслідком. Ці захворювання можуть бути спадковими та спорадичними. Під час гістологічного дослідження мозку після смерті хворих на ТСЕ установлюють ураження нейронів у вигляді дистрофічних змін, вакуолізації нейронів, проліфераџї астроцитів у великих півкулях головного мозку, стовбурі та мозочку. Для реплікачії патологічного пріона $\left(\operatorname{Pr} P^{S c}\right)$ необхідний клітинний пріон $\left(\operatorname{Pr} P^{C}\right)$, а поширення інфекції залежить від рівня продукції останнього в тканинах організму. $\operatorname{Pr}^{C}$ є поверхневим мембранним глікопротеїном, який виконує важсливі функиії, зокрема антиоксидантний, антиапоптичний захист, транспорт деяких іонів та ін. За умов конверсії y патологічну форму $\operatorname{Pr}^{C}$ змінює конформацію молекули та не здатний виконувати свою функиію, $y$ результаті чого виникає порушення різних ланок метаболізму.

Дослідженнями встановлено локалізацію $\operatorname{Pr}^{C}$ у мозочку щурів різного віку. Клітинний пріон виявлено у корі мозочка, зокрема у нейронах молекулярного та зернистого шарів, а також у клітинах Пуркін'є. На тлі вікових змін мозочка локалізація $\operatorname{Pr}^{C}$ не змінюється. Методом імуногістохімії та дот блот аналізу визначено кількість клітинного пріона у щурів різного віку. Зокрема, вміст $\operatorname{PrP}^{C} \in$ найвищим $y$ мозочку шестимісячних шурів, а найнижчим - $y$ тридиятимісячних.

Ключові слова: ЩУРИ, МОЗОЧОК, ВІКОВІ ЗМІНИ, КЛІТИННИЙ ПРІОН, ІМУНОГІСТОХІМІЯ, ДОТ БЛОТ 


\title{
КАЧЕСТВЕННЫЙ АНАЛИЗ КЛЕТОЧНОГО ПРИОНА В МОЗЖЕЧКЕ КРЫС ЛИНИИ WISTAR РАЗНЫХ ВОЗРАСТНЫХ ГРУПП
}

\author{
М. В. Кушкевич, В. В. Влизло \\ inenbiol@mail.lviv.ua
}

Институт биологии животных НААН, ул. Стуса, 38, Львов, 79034, Украина

Прионные инфекиии (трансмиссивные спонгиоформни эниефалопатии ТСЕ) вызывают поражение мозга человека и животных с летальным исходом. Эти заболевания могут быть наследственными и спорадическими. При гистологическом исследовании мозга после смерти больных ТСЕ устанавливают поражение нейронов в виде дистрофических изменений, вакуолизачии нейронов, пролифераиии астроцичтов в больших полушариях головного мозга, стволе и мозжечке. Для репликации патологического приона $\left(\operatorname{Pr}^{S^{S c}}\right)$ необходим клеточный прион $\left(\operatorname{Pr} P^{C}\right), \quad a$ распространения инфекиии зависит от уровня продукции последнего в тканях организма. $\operatorname{Pr} P^{C}$ является поверхностным мембранным гликопротеином, который выполняет важные функиии, в частности антиоксидантную, антиапоптическую защиту, транспорт некоторых ионов $u д p$. В условиях конверсии в патологическую форму $\operatorname{Pr} P^{C}$ изменяет конформачию молекуль и не способен выполнять свою функиию, в результате чего возникает нарушение различных звеньев метаболизма.

Исследованиями установлено локализацию $\operatorname{Pr}^{C}$ в мозжечке крыс разного возраста. Клеточный прион обнаружено в коре мозжечка, в частности в нейронах молекулярного $u$ зернистого слоев, а также в клетках Пуркинье. На фоне возрастных изменений мозжечка локализация $\operatorname{Pr} P^{C}$ не меняется. Методом иммуногистохимии и дот блот анализа определено количество клеточного приона у крыс разного возраста. В частности, содержание $\operatorname{Pr} P^{C}$ является наибольшим в мозжечке шестимесячных крыс, а наименьшим - в тридиятимесячных.

\section{Ключевые слова: КРИСЫ, МОЗЖЕЧОК, ВОЗРАСТНЫЕ ИЗМЕНЕНИЯ, КЛЕТОЧНЫЙ ПРИОН, ИММУНОГИСТОХИМИЯ, ДОТ БЛОТ}

Transmissible sponhioform encephalopathies (TSEs) are result of infection provided by genetic or sporadic cases of prion disease. The infectious agent of the disease is pathological prion $\left(\mathrm{PrP}^{\mathrm{Sc}}\right)$ [1]. Clinically TSE pathogenesis is divided into three distinct phases: infection and peripheral replication of prions; neuroinvasion and replication in the central nervous system (CNS) followed by neurodegeneration [2].

The precursor of $\operatorname{PrP}^{\mathrm{Sc}}$ is the physiological (cellular) prion $\operatorname{PrP}^{\mathrm{C}}$, which is necessary for the disease development. The cellular prion is a 250-amino acid glycoprotein commonly found attached by a glycosylphosphotidylinositol (GPI) anchor to lipid rafts in the plasma membrane. Through a poorly understood process, $\operatorname{PrP}^{\mathrm{C}}$ can undergo post-transcriptional conversion from a predominantly $\alpha$-helical structure to a mainly $\beta$-sheet isoform $\left(\mathrm{PrP}^{\mathrm{Sc}}\right)$. Substantial evidence indicates that $\operatorname{PrP}^{\mathrm{Sc}}$ is the principal if not the unitary component of the agent causing TSEs.
One line of investigation proposes that $\operatorname{Pr}^{\mathrm{C}}$ is an antioxidant that promotes detoxification of reactive oxygen species. Another hypothesis proposes that $\operatorname{PrP}^{\mathrm{C}}$ has cytoprotective activity that blocks internal or environmental factors that initiate apoptosis [3, 4]. In addition, several authors have proposed that $\operatorname{PrP}^{\mathrm{C}}$ participates in transmembrane signaling processes associated with cellular survival, proliferation and differentiation [5].

Spongiform encephalopathy development in the CNS can be analysed by the histological methods. Symmetrically placed well defined degenerative changes causing appearance of round or oval microcysts (vacuolization) in the gray matter of the brain stem were observed [6]. So far the question remains unclear: what actually causes this neuronal cell death? Among possible causes of the neurodegeneration are direct neuronal toxicity of $\mathrm{PrP}^{\mathrm{Sc}}$, loss of $\mathrm{PrP}^{\mathrm{C}}$ function, microglial and astroglial production of neurotoxic proinflammatory cytokines as a 
response to $\mathrm{PrP}^{\mathrm{Sc}}$, indirect disturbance of the synthesis, processing and action of other proteins due to neuronal accumulation of $\mathrm{PrP}^{\mathrm{Sc}}$. It is also possible combination of some or all suggested mechanisms.

The cellular prion is found in the some somatic tissues by Western blotting [7, 8]. However, there are no data on its localization in the cerebellum and quantitative changes in the age-dependent manner.

The aim of the work was to study the cellular prion localization and its level in the cerebellum of of rats of different ages by methods of immunohistochemistry and dot blotting.

\section{Materials and Methods}

Manipulation with the animals were carried out under the principles of the "European Convention for the Protection of Vertebrate Animals Used for Experimental and Other Scientific Purposes" (Strasbourg, 1986), the Decision of the First National Congress on Bioethics (Kyiv, 2001) and the Law of Ukraine "On Protection Animals from Brutal Treatment" (Kyiv, 2006).

Research was carried out on the males of laboratory rats Rattus norvegicus var. alba, Wistar line, which were held under standard vivarium conditions. The animals aged one, six and thirty months were decapitated under ether anesthesia and the cerebellum took out for this research.

For immunohistochemical studies the tissue was fixed, washed and dewatered; after that, the paraffin blocks formation were performed using standard techniques [9]. The tissue sections were cut using the microtome Microm HM 340E (the thickness of each fragment was 7 microns). The obtained tissue fragments were washed in TBST $(\mathrm{pH}$ 7.6). After that, isolated fragments of the tissue were incubated with monoclonal primary antibodies (Antibody mAB6H4; Prionics, Switzerland) at $+4^{\circ} \mathrm{C}$ for $12 \mathrm{~h}$. Dako firm (Denmark) reagent kit for immunohistochemical studies was used. After washing the sections of the tissue were stained by Mayer hematoxylin and placed in aqueous permanent mounting medium (Dako, Denmark). Histological studies were performed on the microscope Axioskop 40 (Carl Zeiss, Germany). Tissue sections painted only with hematoxylin were used as a control. The amount of cellular prion in the tissue sections was determined using a program VideoTest 5.0 [10].

A dot blot analysis of the cerebellum was performed. For that, the tissue was homogenized, lysed in a special buffer with the addition of $0.001 \%$ mixture of proteinase inhibitors (Sigma, Germany) and centrifuged. The protein level was measured by Lowry method [11]. The samples with the same concentration of the protein were deposited on polyvinildiftorid (PVDF) membrane (Millipor, USA), which was incubated with monoclonal primary antibodies (Antibody mAB6H4; Prionics, Switzerland) at $+4^{\circ} \mathrm{C}$ for $12 \mathrm{~h}$, and secondary polyclonal goat antimouse antibodies which is conjugated with alkaline phosphatase (Sigma, Germany) at $+22{ }^{\circ} \mathrm{C}$ during $60 \mathrm{~min}$. Detection of the immune complexes was carried out using a substrate for alkaline phosphatase CDP-Star (Tropix, UK). Visualization was performed using X-ray film Retina XBM (Lizoform Medical, Ukraine) and film development kit for films (Kodak, Japan) [9].

Student coefficient was calculated to assess the probable difference between the statistical characteristics of alternative data set. The accurate approximation was when $\mathrm{P} \leq 0.05$ [12]. Statistical analysis of results was carried out using the programs Excel and Origin.

\section{Results and Discussion}

Cerebellum is the central organ of balance and coordination. On its surface there are many foliums and fissures, which greatly increase its area. In side of each gyrus is a thin layer of white matter which is coated with a layer of gray matter (the cortex). In the cerebellar cortex there are three layers: outer (molecular), medium (ganglionic or a layer of pear shaped neurons), and internal (granular). The molecular layer contains basket and stellate inhibitory neurons. Efferent cells of the 
cerebellar cortex (pear-shaped Purkinje cells) arranged in a row and form the ganglionic layer. Granular layer is the deepest and adjacent to the white matter. In this layer are the granule cells and two types of Golgi cells (with short and long axons) and horizontal fusiform cells [13, 14]. Granule cells have small perykarion with rounded large nucleus (fig. 1a, 2a, 3a).

At the one-month old rats' cerebellum sections the molecular layer contained a lot of

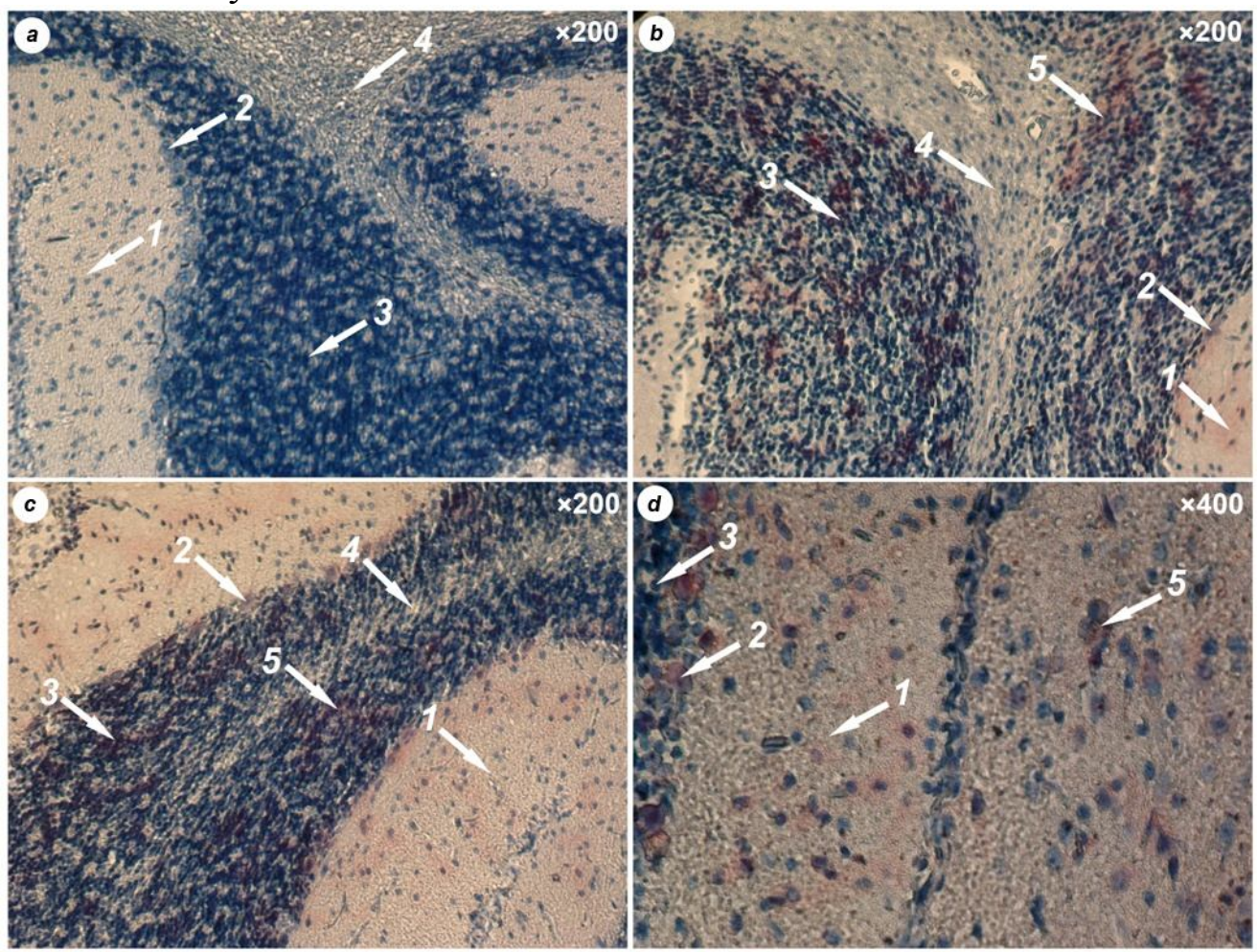

Fig. 1. Cerebellum of the one month rats: $a-$ control; $b, c, d$ - immunohistochemistry; 1 - molecular layer; $2-$ Purkinje cell layer; 3 - granule cell layer; 4 - white matter; 5 - localization of the cellular prion

(Light microscopy, hematoxylin staining)

Quantity of the perikarions in the molecular layer of the six-months old rats' cerebellum is decreased due to proliferation of glia and nerve fibers and neuronal death. The localization of the cellular prion is unchanged under these conditions (fig. 2b-d), but its amount significantly is increased especially in Purkinje cells compared to one-month old rats (589.41 \pm 7.42 standard units).

Some age-related changes in the tissue structure are observed in the cerebellum of thirty-months old animals. In particular, the amount of Purkinje cells and granular layer neurons is significantly reduced, so that the neurons and glial cells. Purkinje cells were large with conspicuous nucleus and tightly side by side. The granular layer was also thick with many neurons. In rats of this age the $\mathrm{PrP}^{\mathrm{C}}$ is detected in the cerebellar cortex, particularly in neurons of the molecular and granular layers, as well as in the Purkinje cells (fig. 1bd). 397.29 \pm 10.64 standard units of the cellular prion were calculated in young animals' tissue by quantification of digitizing photographs.

granular layer is flattened, while the content of the white matter in foliums center is increased. As it is known Purkinje cells are the main functional element of the cerebellar cortex. In normal operation of the cortex activity they directed all other elements, afferent fibers. Only Purkinje cells axons exit from the cerebellar cortex and implement a regulatory effect on the body by sending impulses to the subcortical nuclei of the cerebellum located in the white matter. The cellular prion of the sixmonths old rats' cerebellum is localized in the granular layer of neurons and nerve fibers of the molecular layer (fig. 3b-d) $(321.93 \pm 5.37$ standard units). 

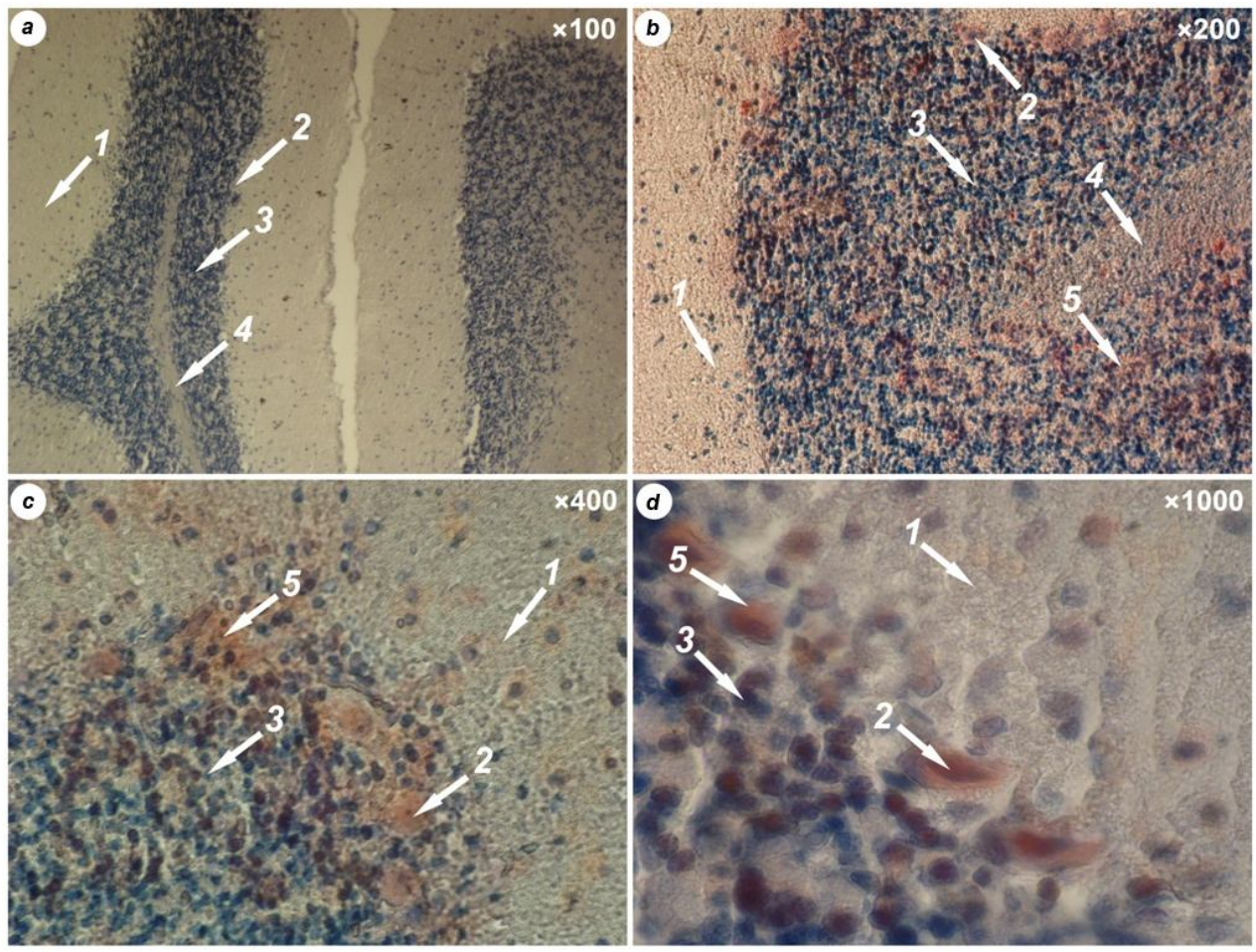

Fig. 2. Cerebellum of the six-months rats: $a-$ control; $b, c, d$ - immunohistochemistry; 1 - molecular layer; $2-$ Purkinje cell layer; 3 - granule cell layer; 4 - white matter; 5 - localization of the cellular prion

(Light microscopy, hematoxylin staining)

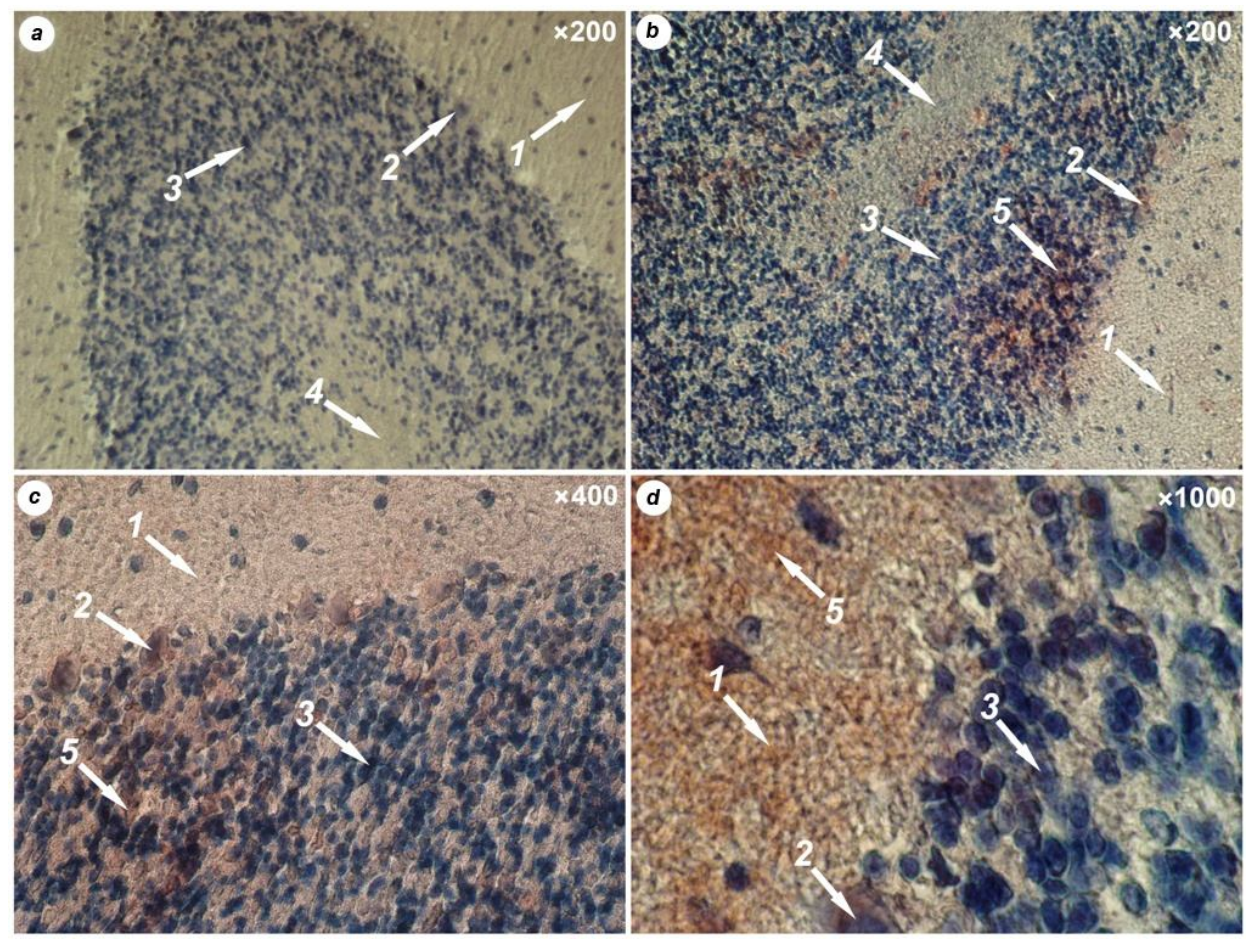

Fig. 3. Cerebellum of the thirty months rats: a - control; $\mathrm{b}-\mathrm{d}-$ immunohistochemistry, $1-$ the molecular layer; $2-$ Purkinje cell layer; 3 - granule cell layer; 4 - white matter; 5 - localization of the cellular prion (Light microscopy, hematoxylin staining) 
Production of endogenous $\mathrm{PrP}^{\mathrm{C}}$ is essential for TSE pathogenesis. The requisite role of $\mathrm{PrP}^{\mathrm{C}}$ in TSE pathogenesis has been unequivocally demonstrated in experiments using $\operatorname{PrP}^{\mathrm{C}}$ knockout mice. PrP null mice (Prnp 0/0) do not produce $\operatorname{PrP}^{\mathrm{C}}$ and are completely resistant to experimental TSE infection [15].

$\operatorname{PrP}^{\mathrm{C}}$ is found in lysosomes in healthy brain. During the penetration of $\operatorname{PrP}^{\mathrm{Sc}}$ the lysosomes of nerve cells overflow dead residues resulting enzyme abnormalities in these organelles. They die and vacuoles form in their place. Later the whole cell is destroyed, the pathogenic prion out of it and strike other nerve cells [6].

The amount of cellular prion in the cerebellum of rats of different ages is also determined by dot blot analysis. As in previous studies its level increased by $17 \%$ in tissues of mature animals (six months) compared to young animals (one month). $\operatorname{PrP}^{\mathrm{C}}$ level is decreased by $15 \%$ in the tissue of old animals (30 months) compared to mature animals (fig. 4).

Similar results are obtained by Mar Cuadrado-Tejedor with collaborators. They analyzed the cortex and hippocampus areas of the rats' brain by the Western blot analysis [16]. The $\operatorname{PrP}^{\mathrm{C}}$ level is increased in both areas in mature animals (38 weeks) compared to young (six weeks), and it is decreased in old animals (56 weeks). Moreover, the amount of non glycosylated forms of the protein increased with aging.

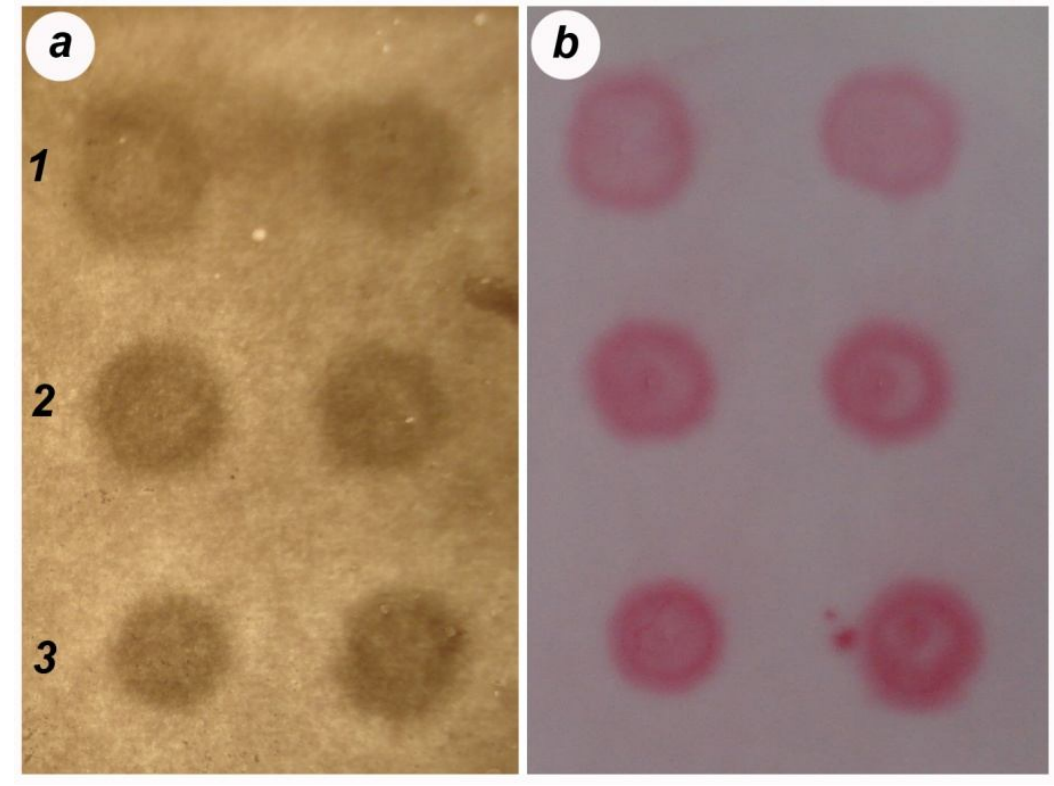

Fig. 4. PrP ${ }^{\mathrm{C}}$ level in the cerebellum of rats of different ages $(a-$ dot blot analysis; $b-$ level of total protein in the samples is the same (staining Ponceau red): 1 - one month; 2 - six months; 3 - thirty months

Thus, the cellular prion level is higher in the cerebellum of six months old rats compared to other age groups of the animals. Its amount is decreased in thirty months rats. Perhaps the abnormal prions can be formed during excess $\mathrm{PrP}^{\mathrm{C}}$ production, especially when there is extinction (destruction) of nerve cells and prion acts as a waste. It is also possible that different harmful factors affect the $\operatorname{PrP}^{\mathrm{C}}$ gene causing its pathogenic mutation that provoke the formation of $\operatorname{PrP}^{\mathrm{Sc}}$. It may be one of the causes of the sporadic form of
Creutzfeldt-Jakob disease (CJD). It is often registered and presented $85 \%$ of all cases of CJD [17].

\section{Conclusions}

1. The localization of cellular prion in the cerebellum of rats of different age groups was demonstrated using immunohistochemical analysis. The $\operatorname{PrP}^{\mathrm{C}}$ was detected in the cerebellar cortex, particularly in neurons of the 
molecular and granular layers and in the Purkinje cells.

2. The $\operatorname{PrP}^{\mathrm{C}}$ level slightly increases in the cerebellum of six months old animals, compared to young animals (one month). The increase in the age of rats until 30 months leads to slightly decrease of the $\operatorname{PrP}^{\mathrm{C}}$ level in the cerebellum.

Prospects for future research is to examine the tissue localization and level of the cellular prion in other prion replikating organs of animals.

1. Prusiner S. B. Genetic and infectious prion diseases. Arch. Neurol, 1993, 50: 11291153.

2. Hegde R. S., Tremblay P., Groth D. et. al. Transmissible and genetic prion diseases share a common pathway of neurodegeneration. Nature, 1999, 402: 822-826.

3. Vlizlo V. V., Stadnyk V. V., Major Ch. Ya., Verbitsky P. I. Fisiologichnyi prion ta yogo rol u funktsionuvanni klityny [Physiological prion and its role in the functioning of the cell]. Animals biology, 2008, 10 (1-2): 9-23 (in Ukrainian).

4. Westergard L., Christensen H., Harris D. The cellular prion protein $\left(\operatorname{PrP}^{\mathrm{C}}\right)$ : its physiological function and role in disease. Biochim. Biophys. Acta, 2007, 1772: 629-644.

5. Linden R. Physiology of the Prion Protein. Physiol Rev, 2008, 88: 673-728.

6. Verbitsky P. I. Gubchastopodibna entsefalopatiya VRCH ta inshi prionni infektsii [Spongioform encephalopathy in cattle and other prion infections]. Kyiv: Vetinform, 2005. 240 p. (In Ukrainian).

7. Major Ch. Ya. Vmist fisiologichnogo priona $u$ peryferychnij chastyni prionreplikujuchoi systemy shchuriv za dii preparativ glikozaminoglikanovogo rjadu [The content of physiological prion in peripheral part of rats prionreplication system under the action of glicoseaminoglycans series drugs]. $\mathrm{PhD}$ thesis, Institute of Animal Biology NAAS of Ukraine. Lviv, 2010. 16 p. (In Ukrainian).

8. Stadnyk V. V. Biochimichni osoblyvosti prion-proteina za normy ta patologii [Biochemical features of prion-protein at health and disease]. $\mathrm{PhD}$ thesis, Institute of Animal Biology NAAS of Ukraine. Lviv, 2008. 15 p. (In Ukrainian).

9. Vlizlo V. V. Laboratorni metody doslidzhen u biologii, tvarynnytstvi ta veterynarnij medytsyni: dovidnyk [Laboratory methods of research in biology, stockbreeding and veterinary medicine: a guide]. Lviv: Spolom, 2012. 764 p. (In Ukrainian).

10. www.videotest.ru.

11. Lowry O. N., Rosenbrough N. I., Forr A. R. et al. Protein measurement with the Folin phenol reagent. J. Biol. Chem, 1951, 193 (1): 265275.

12. Lakin G. F. Biometriya [Biometry]. Moscow: HS, 1990. 352 p. (In Russian).

13. Kuznetsov S. L., Mushkambarov N. N., Horyachkyna V. L. Rukovodstvo-atlas po gistologii, tsitologii $i$ embriologii [Guide-atlas in histology, cytology and embryology]. Moscow: DyaMorf, 1999 (in Russian).

14. Kuehnel W. Color Atlas of Cytology, Histology and Microscopic Anatomy. New York: Thieme Stuttgart, 2003. $534 \mathrm{p}$.

15. Kingsbury D. T., Smeltzer D. A., Gibbs C. J., Gajdusek D. C. Evidence for normal cell-mediated immunity in scrapie-infected mice. Infect. Immun, 1981, 32: 1176-1180.

16. Cuadrado-Tejedor M., Irujo A., Paternain B.et al. Cellular Prion Protein and Sexual Dimorphic. Areas in Rodents. Correlates with Alzheimer Disease. Neuroscience \& Medicine, 2011, 2: 384-391.

17. Zou R. S., Fujioka H., Guo J.-P. et al. Characterization of spontaneously generated prion like conformers in cultured cells. Aging, 2011, 3(10): 1-17. 